\title{
Mycoplasma gallisepticum infection in the grey partridge Perdix perdix: outbreak description, histopathology, biochemistry and antioxidant parameters
}

Frantisek Vitula ${ }^{1 \dagger}$, Lucie Peckova ${ }^{1}$, Hana Bandouchova ${ }^{1 \dagger}$, Miroslav Pohanka $^{2 \dagger}$, Ladislav Novotny ${ }^{3}$, David Jira ${ }^{1}$, Jiri Kral ${ }^{1}$, Karel Ondracek ${ }^{1}$, Jitka Osickova ${ }^{1}$, Dagmar Zendulkova ${ }^{4}$, Katerina Rosenbergova ${ }^{4}$, Frantisek Treml ${ }^{4}$ and Jiri Pikula ${ }^{1 *+}$

\begin{abstract}
Background: The grey partridge is an important game bird in Europe that has declined considerably over the last decades. The production and release of farm-bred birds can be threatened by infectious agents. The objective of this study was to describe the outbreak, pathology, and blood and tissue biochemical responses in a flock of grey partridges naturally infected with Mycoplasma gallisepticum.

Results: Morbidity and mortality rates were $100 \%$ and $60 \%$, respectively. Necropsy revealed an accumulation of caseous exudate within the infraorbital sinuses, tracheitis, pneumonia and airsacculitis. There were significant increases in activities of lactate dehydrogenase, creatine kinase and amylase, and levels of total protein and glucose in Mycoplasma-infected birds when compared to control. Catalase showed significantly lower activity in the heart, lungs, liver and gonads of Mycoplasma-infected birds. Glutathione-S-transferase activity was elevated in the eye and the associated infraorbital sinus and kidneys, and decreased in the liver. Decreased levels of reduced glutathione were found in the heart, kidneys, liver and gonads. The activity of glutathione reductase was lower only in the lungs. Compared to healthy birds, mycoplasmosis in the grey partridge caused significant differences in the level of lipid peroxidation in lungs and plasma $(p<0.05)$, while the ferric reducing antioxidant power was lower in the heart and kidneys ( $p<0.01$ ). Significant correlations among responses of the antioxidant parameters were found namely in the heart, lungs, spleen, liver and plasma. There were also numerous significant inter-tissue correlations of all the studied antioxidant parameters.

Conclusions: The present study demonstrates the high susceptibility of grey partridges to natural infection by $M$. gallisepticum, the severity of the disease based on histopathology, and the modulation of blood chemical profiles and oxidative stress-associated parameters in the avian hosts, thus enhancing the understanding of the pathogenesis of mycoplasmosis in birds. Moreover, the reported reference values can be useful for the evaluation of the state of health in grey partridges.
\end{abstract}

\footnotetext{
* Correspondence: pikulaj@vfu.cz

† Contributed equally

'Department of Veterinary Ecology and Environmental Protection, Faculty of Veterinary Hygiene and Ecology, University of Veterinary and Pharmaceutical

Sciences, Brno, Czech Republic

Full list of author information is available at the end of the article
} 


\section{Background}

The grey partridge Perdix perdix, a famous bird native to Europe and introduced to many parts of the world, has shown a marked population decline throughout Europe since the second half of the $20^{\text {th }}$ century [1]. Factors driving this decline include a sharp decrease in chick survival due to pesticide use, habitat loss due to agricultural intensification and mechanisation, lower hatching success, and increased predation [2]. As this avian species is both of conservation and commercial game management concern, captive-bred grey partridges are widely used for repopulation purposes $[3,4]$. The release of farm-bred birds presents some risks that can combine and result in high mortality rate in the reintroduced population [5]. Game bird reintroductions have been reported to fail because of behavioural deficiencies, post-release predation, lower disease resistance, disease outbreaks, and genetic differences between the released and the wild birds [3,5-7]. Birds originating from infected captive flocks may introduce new agents into the wild populations or suffer from adverse effects of the parasite burdens they carry $[8,9]$. The release of other game birds, such as Phasianus colchicus pheasants and Alectoris rufa red-legged partridge, can also prove harmful for grey partridges due to competition and shared pathogens [2].

An outbreak of mycoplasmosis occurred at a game bird farm (Moravia, Czech Republic) producing birds for release and affected a flock of breeding grey partridges in 2010. Laboratory diagnosis confirmed Mycoplasma gallisepticum, the most economically significant mycoplasma pathogen of poultry $[10,11]$. This organism has already been reported to cause disease in game birds including pheasants, chukar and red-legged partridges, bobwhite quail, Japanese quail and peafowl [11-15]. Recent isolations of the agent from passerines with conjunctivitis and the spread of the infection throughout eastern USA and Canada have warranted its classification among emerging infectious diseases in wildlife [16,17].

Mycoplasma infections are known to be associated with oxidative damage of host cells and tissues due to reactive oxygen species generated by both the immune system of the host and the bacterium as its primary virulence factor [18-24]. Resistance to oxidative stress, therefore, seems to be crucial for mycoplasmas to survive within the host [21]. Responses of the host cell antioxidant defence systems to the human pathogen Mycoplasma pneumoniae have been studied extensively in vitro using human cell cultures [18-20,23,24]. M. gallisepticum infection of cultured chicken embryo fibroblasts has also demonstrated that attachment of viable mycoplasmas to cells is crucial to decrease catalase activity and that this lower enzyme activity may be important for the development of cytopathic effects [22].
With the exception of one study on the oxidative stress and alterations of antioxidant status in blood samples from goats infected with Mycoplasma agalactiae [25], there are no in vivo reports concerning other animal species and birds in particular. While clinical signs, lesions, pathogenicity, epizootiology, laboratory diagnosis and control of the M. gallisepticum infection in game birds are well described [11-15], little is known about the effect of the pathogen on the avian host regarding oxidative stress and biochemistry in association with histopathological findings. The molecular and cellular events that lead to the development of lesions and clinical disease are still obscure [10]. Thus, the objective of this study was to describe the outbreak and evaluate normal blood and tissue biochemical parameters as well as biochemical responses and pathology in a flock of grey partridges naturally infected with $M$. gallisepticum.

\section{Methods}

\section{Experimental birds and samples collected}

One-year-old captive-bred adult grey partridges were used in the study. The birds were kept at a game bird farm (Moravia, Czech Republic). Control healthy birds (44 males and 44 females) were blood sampled for normal biochemistry and evaluation of gender differences. A total of 5 suspected Mycoplasma-infected pairs of birds showing pronounced clinical signs of respiratory disease were blood sampled and then sacrificed by decapitation in order to collect samples for bacterial laboratory diagnosis and organs including the heart, eye and the associated infraorbital sinus, central nervous system, lungs, kidney, spleen, liver and gonads for histopathology and measurements of antioxidant parameters. A control group of 5 healthy pairs were also sampled in this way. The study was performed in compliance with the laws for the protection of animals against cruelty as approved by the Ethical Committee of the University of Veterinary and Pharmaceutical Sciences Brno, Czech Republic.

\section{Bacterial diagnosis (Mycoplasma culture and identification)}

Clinical specimens were collected and cultured as previously recommended [26]. Swabs from the trachea, nares and conjunctival sacs, the inflammatory content of infraorbital sinuses and a piece of lung tissue were plated onto the mycoplasma agar and inoculated into the broth for the isolation of avian mycoplasmas [27], as modified by Bradbury [28]. Samples were incubated at $37^{\circ} \mathrm{C}$ in an atmosphere of $5 \% \mathrm{CO}_{2}$. Broths were examined daily for colour change in the $\mathrm{pH}$ indicator and plates every 2-3 day for colony growth. The Mycoplasma spp. isolates were further identified using the nested polymerase chain reaction (PCR). The presence 
of M. gallisepticum DNA was detected using a nested PCR based on the amplification of the 16S rRNA gene sequence specific for $M$. gallisepticum (accession number M22441). Primers for the $1^{\text {st }}$ and $2^{\text {nd }}$ PCR were selected using the Vector NTI Suite 5.5 (INFORMAX) and synthesised on a commercial basis by the Generi Biotech company (Czech Republic). Sequence of primers for the $1^{\text {st }}$ PCR reaction are Sn: 5'ATG CTG AGA GGT AGA ATA ACC 3' and Asn: 5'CCA CCT TAC GGA TTT GC 3'; for the $2^{\text {nd }}$ PCR Sn: 5'GGC GAA GGC GAG GAC TTG GG 3' and Asn: 5'GCA CCG AAG TAT TCG CTC CGA CAC 3'. The NucleoSpin Tissue Kit (Machery - Nagel, Germany) was used to isolate the total DNA from the sample as described by the producer. Both PCR reactions were performed in $20 \mu \mathrm{l}$ of the reaction mixture in a Biometra $T$-personal thermocycler (Germany). The reaction mixture contained PPP Master Mix (i.e., $200 \mu \mathrm{M}$ of each dNTP, $2.5 \mathrm{mM} \mathrm{MgCl}_{2}, 2 \mathrm{U}$ Taq Purple DNA polymerase; Top Bio, Czech Republic) and primers in the concentration of $25 \mathrm{pmol} / \mu \mathrm{l}$. Amplification in both reactions included 30 cycles of denaturation at $94^{\circ} \mathrm{C}$ for $35 \mathrm{~s}$, annealing at $49^{\circ} \mathrm{C}$ (the $1^{\text {st }}$ PCR) or $66^{\circ} \mathrm{C}$ (the $2^{\text {nd }} \mathrm{PCR}$ ) for $25 \mathrm{~s}$ and elongation at $72^{\circ} \mathrm{C}$ for $90 \mathrm{~s}$. The PCR product (volume $10 \mu \mathrm{l}$ ) gained in the $2^{\text {nd }}$ PCR was analysed by electrophoresis in the $2 \%$ agarose gel stained with ethidium bromide and visualised using an UV transilluminator. The specific PCR product of $130 \mathrm{bp}$ was compared with the molecular weight marker O'GeneRuler DNA Ladder Mix (Fermentas International Inc., USA).

Apart from the mycoplasma culture, routine bacteriological examination was performed. Samples collected from the liver, spleen, kidneys, lungs, infraorbital sinuses and air sacs were aerobically incubated at $37^{\circ} \mathrm{C}$ for 48 hours on blood agar and MacConkey agar. The bacterial growths were then identified by standard methods.

\section{Serological tests}

Control healthy birds and partridges suspected from Mycoplasma infection were serologically examined for avian respiratory infections including 1) Newcastle disease (haemagglutination inhibition test with VLDIA039 HAG-NDL live antigen for use in the HI test and VLDIA053 HAR-NDL monospecific antiserum for use as a positive control in the HI test; GD-Animal Health Service, Deventer, the Netherlands), 2) avian influenza (AI Ab enzyme-linked immunosorbent assay ELISA; IDEXX Laboratories, Inc., Westbrook, Maine, USA), 3) infectious bronchitis (IBV Ab ELISA; IDEXX Laboratories, Inc., Westbrook, Maine, USA), 4) infectious laryngotracheitis (agar gel immunodiffusion with VLDIA014 AGA-ILT live antigen for use in the AGID test for infectious laryngotracheitis and VLDIA022 AGP-ILT monospecific infectious laryngotracheitis antiserum for use as a positive control in the AGID test and VLDIA030 SPF-CH chicken negative control serum for use as a negative control in most poultry assays; GD-Animal Health Service, Deventer, the Netherlands), 5) avian rhinotracheitis (APV Ab ELISA; IDEXX Laboratories, Inc., Westbrook, Maine, USA), 6) avian chlamydiosis (Chlamydia complement fixation test; Institute Virion Ltd., Zurich, Switzerland) as well as antibodies against 7) M. gallisepticum (MG Ab ELISA; IDEXX Laboratories, Inc., Westbrook, Maine, USA).

\section{Histopathology}

Specimens of heart, eye and the associated infraorbital sinus, central nervous system, lungs, kidney, spleen, liver and gonads (ovaries and testes) were collected and placed in $10 \%$ buffered formalin during autopsy, and were treated using a routine histological technique and embedded in paraffin. Sections of $5 \mu \mathrm{m}$ thicknesses were made from the paraffin blocks and these were stained with haematoxylin and eosin.

\section{Plasma biochemistry}

Blood (1 ml) was collected from the right jugular vein using the Omnican ${ }^{\circledR} 40$ (Braun, Germany). Whole blood was placed in heparinised tubes (Leciva inj., Prague), centrifuged immediately, and plasma was removed and frozen $\left(-20^{\circ} \mathrm{C}\right)$. Within a few days, plasma was analysed using an automated analyser (SPOTCHEM ${ }^{\text {TM }}$ EZ SP4430, ARKRAY, Japan) for aspartate aminotransferase $(\mu \mathrm{kat} / \mathrm{l})$, alkaline phosphatase $(\mu \mathrm{kat} / \mathrm{l})$, lactate dehydrogenase $(\mu \mathrm{kat} / \mathrm{l})$, creatine kinase $(\mu \mathrm{kat} / \mathrm{l})$, alanine aminotransferase $(\mu \mathrm{kat} / \mathrm{l})$, total protein $(\mathrm{g} / \mathrm{l})$, total cholesterol ( $\mathrm{mmol} / \mathrm{l})$, high-density lipoprotein cholesterol ( $\mathrm{mmol} / \mathrm{l})$, triglycerides $(\mathrm{mmol} / \mathrm{l})$, glucose $(\mathrm{mmol} / \mathrm{l})$, amylase ( $\mu \mathrm{kat} /$ l), uric acid ( $\mathrm{mmol} / \mathrm{l})$, calcium $(\mathrm{mmol} / \mathrm{l})$ and phosphorus (mmol/l).

\section{Antioxidant parameters}

The antioxidant parameters were assayed in tissues (heart, eye and the associated infraorbital sinus, central nervous system, lungs, kidney, spleen, liver, ovaries and testes) and plasma samples were collected at the time of autopsy and kept at $-80^{\circ} \mathrm{C}$ until use. Biochemicals, enzymes and other chemicals used in the study were purchased from Sigma-Aldrich (Prague, Czech Republic) and were of the highest available commercial grade. The tissues were homogenised on ice using a mechanical homogeniser (100 $\mathrm{mg}$ of tissue in $1 \mathrm{ml}$ ) in $50 \mathrm{mM}$ potassium phosphate buffer $\left(\mathrm{KH}_{2} \mathrm{PO}_{4}\right.$ with $1 \mathrm{mM}$ EDTA, pH 7.4) for assessment of catalase (CAT) activity and in phosphate buffered saline (PBS, $\mathrm{pH}$ 7.2) for other parameters. The postmitochondrial supernatant was collected after centrifugation $\left(30 \mathrm{~min}\right.$ at $30,000 \mathrm{~g}$ at $4^{\circ} \mathrm{C}$ for $\mathrm{CAT}$ and $15 \mathrm{~min}$ at $10,000 \mathrm{~g}$ at $4^{\circ} \mathrm{C}$ for the other 
parameters) and stored frozen at $-80^{\circ} \mathrm{C}$ until biochemical analyses. The methods for the assessment of most of the biochemical markers measured are described in our previous article [29]. Briefly, glutathione- $S$-transferase (GST) activity was measured spectrophotometrically using 1-chloro-2,4-dinitrobenzene. The concentration of reduced glutathione (GSH) was determined using 5,5'dithiobis-2-nitrobenzoic acid (DTNB) as a chromogen. Activity of glutathione reductase (GR) was determined from the rate of NADPH oxidation. The level of lipid peroxidation in avian tissues was assessed as total thiobarbituric acid reactive species (TBARS). Activity of CAT was evaluated spectrophotometrically at $240 \mathrm{~nm}$ in cuvettes as the rate of hydrogen peroxide breakdown in the mixture containing $0.09 \%$ hydrogen peroxide in 50 mM TRIS/0.1 mM EDTA buffer [30]. The protein concentrations were determined by the method using the Folin-Ciocalteu phenol reagent. The GENios spectrophotometric microplate reader (Tecan Group, Switzerland) was used to measure the absorbance in all assays and the VARIAN CARY 50 Bio spectrophotometer (Varian, USA) was used for measuring absorbance of solutions in cuvettes. The total antioxidant capacity was measured using the ferric reducing antioxidant power assay (FRAP). The FRAP assay was performed as described previously [31], with minor modifications. In the first round, the FRAP reagent was prepared as a mixture of $2.5 \mathrm{ml}$ of $10 \mathrm{mM} \mathrm{2,4,6-tris(2-pyridyl)-s-tria-}$ zine (TPTZ) in $40 \mathrm{mM} \mathrm{HCl}$ and $2.5 \mathrm{ml}$ of $20 \mathrm{mM} \mathrm{FeCl}_{3}$ in $25 \mathrm{ml}$ of $0.1 \mathrm{M}$ acetate buffer $\mathrm{pH}$ 3.6. The freshly prepared FRAP reagent was incubated at $37^{\circ} \mathrm{C}$ for 10 minutes. The volume of $30 \mu \mathrm{l}$ of the tissue or plasma sample was mixed with $200 \mu \mathrm{l}$ of the FRAP reagent and then with distilled water up to $1 \mathrm{ml}$. After $10 \mathrm{~min}$ of incubation, the mixture was centrifuged at $10,000 \mathrm{~g}$. A blank sample was prepared in the same way as described above but saline solution was used instead of the tissue or plasma sample. Absorbance of the supernatant was measured at $593 \mathrm{~nm}$ against the blank.

\section{Statistical analysis}

Statistica for Windows ${ }^{\circledR} 7.0$ (StatSoft, Tulsa, OK, USA) was used to compare different groups by one-way analysis of variance (ANOVA) and post-hoc analysis of means by the LSD test. The homogeneity of variances was tested by Levene's test. Non-homogenous parameters, as determined by Levene's test, were log-transformed prior to analysis. In these cases, the nonparametric Kruskal-Wallis test was used for comparing the groups. A post-hoc power analysis was conducted to show that the sample size of 10 healthy and 10 infected birds in this study provided sufficient statistical power for comparing tissue biochemical parameters. Values of $p<0.05$ and $p<0.01$ were considered statistically significant and highly significant, respectively, for all tests. Spearman rank order correlations were used to assess the relationships among the measured parameters.

\section{Results}

\section{Outbreak description}

An outbreak of respiratory disease occurred in a flock of adult grey partridges kept at a game bird farm (Moravia, Czech Republic). The infection developed gradually in April to May 2010, culminated by morbidity of $100 \%$ and $60 \%$ (i.e., a total of 68 partridges) died within three to four weeks of appearance of clinical signs. Clinical signs included nasal and ocular discharge and dyspnoea with laboured open-mouth breathing, eyelid and infraorbital sinus swelling, lethargy, poor intake of feed and weight loss. There was a marked drop in egg production. Culture revealed Mycoplasma spp. in tracheal swabs only. A slight colour change (acidity) appeared in the broth medium on the $4^{\text {th }}$ day and first centered mycoplasma colonies were recognized on plates on the $5^{\text {th }}$ day of incubation. The isolated strain was further identified as M. gallisepticum using the nested PCR methods (Figure 1). Bacteriological culture of the liver, spleen, kidneys, lungs, small intestinal content, infraorbital sinuses and air sacs yielded Escherichia coli from infraorbital sinuses, lungs and air sacs. Serological tests for Newcastle disease, avian influenza, infectious bronchitis, infectious laryngotracheitis, avian rhinotracheitis and avian chlamydiosis were negative in birds included in the control healthy and Mycoplasma-infected groups of partridges. The titre of antibodies against $M$. gallisepticum ranged from 1404 to 5884 in the Mycoplasmainfected group. Necropsy revealed an accumulation of caseous exudate within the infraorbital sinuses, tracheitis, pneumonia and airsacculitis. Histopathological

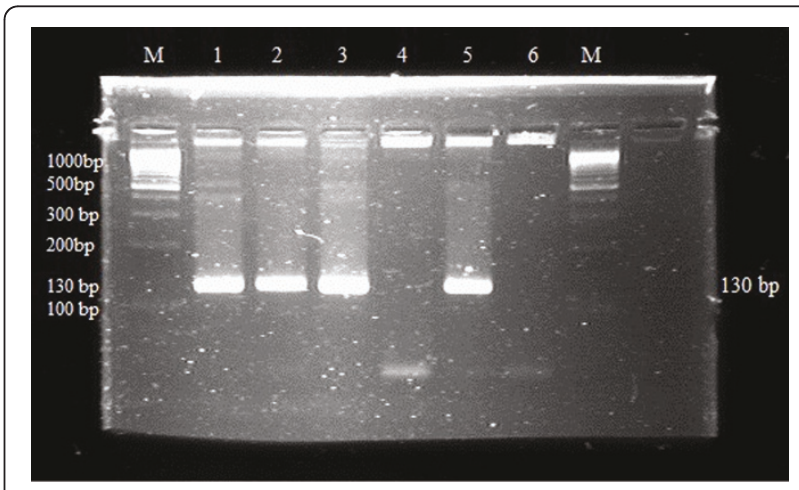

Figure 1 Detection of $M$. gallisepticum by nested PCR. M = Molecular size marker, 100 bp DNA ladder (O'GeneRuler ${ }^{\mathrm{TM}}$ DNA Ladder Mix, Fermentas International Inc., USA). 1 to 3 -positive samples, 4 - a negative sample, 5 - positive control, 6 - negative control. 
findings can be summarised as severe purulent infraorbital sinusitis, moderate purulent tracheitis with marked epithelial hyperplasia, moderate to severe purulent bronchitis and extensive purulent and necrotic pneumonia with secondary bacterial colonisation of necrotic areas. Figures $2 \mathrm{~A}$ and $2 \mathrm{~B}$ show the comparison of the normal tracheal tissue and tracheitis with inflammatory cell infiltration in M. gallisepticum-infected birds. Likewise,

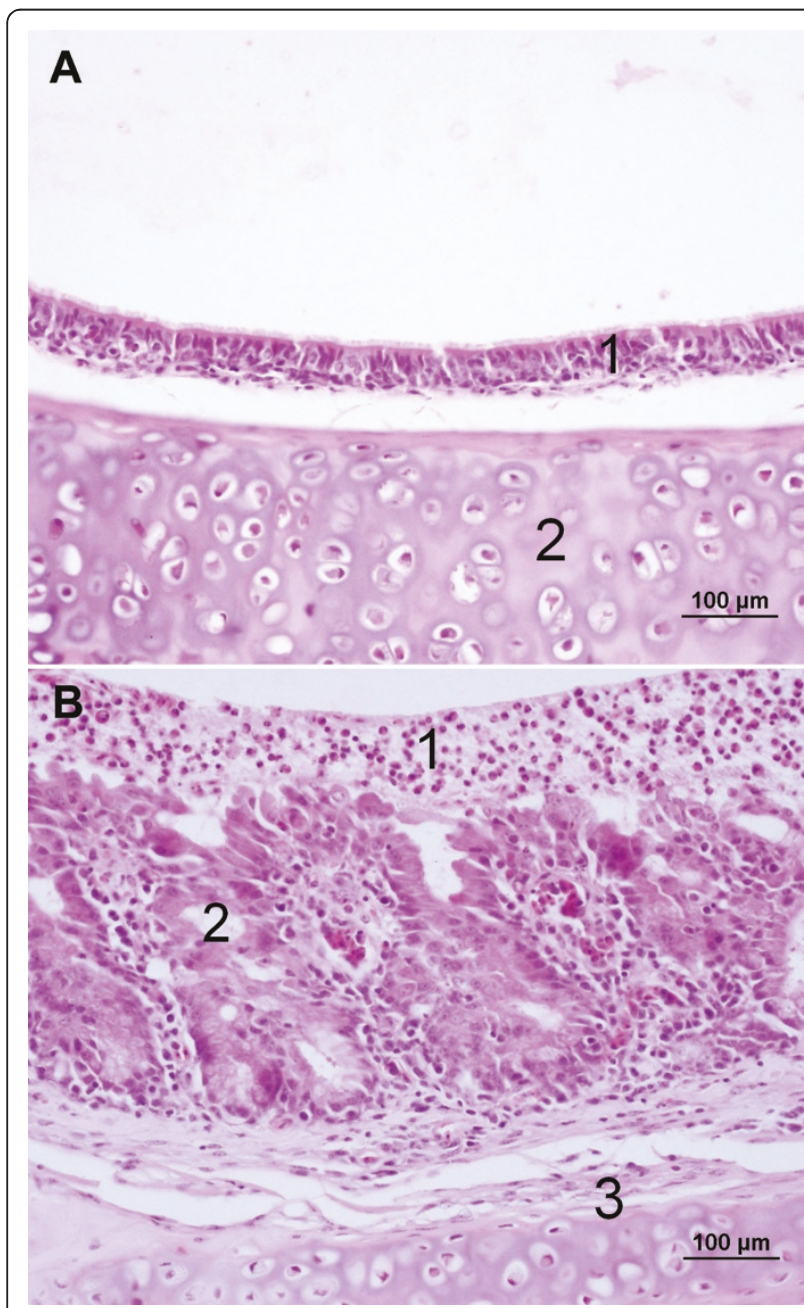

Figure 2 Comparison of normal tracheal tissue and tracheitis with inflammatory cell infiltration in $M$. gallisepticum-infected birds. Figure 2A: Trachea of a partridge from the control group. Normal mucosa lined with a pseudo-stratified columnar epithelium with kinocilia (1) and a fibrocartilaginous layer (2) are presented. No signs of inflammation were observed in any of the tracheal layers. Epithelial detachment is artificial due to sample processing. H\&E stain. Figure 2B: Trachea of a partridge infected with $M$. gallisepticum. The inflammatory exudate, composed mostly of heterophils, is adhered to the epithelium (1). The epithelium is moderately hyperplastic with loss of the kinocilia and lamina propria is moderately infiltrated by lymphocytes and plasma cells (2). The fibrocartilaginous layer (3) is composed of the dense connective tissue mildly infiltrated by lymphocytes and plasma cells, and the perichondrium and hyaline cartilage. H\&E stain.
Figures $3 \mathrm{~A}$ and $3 \mathrm{~B}$ of normal and mycoplasmal infraorbital sinus, respectively, demonstrate the serious nature of pathology in this tissue and Figures $4 \mathrm{~A}$ and $4 \mathrm{~B}$ show the comparison of normal and necrotic lung tissues.

\section{Biochemistry and antioxidant parameters}

Table 1 presents normal plasma chemical profiles in healthy adult grey partridges as well as values measured in Mycoplasma-infected birds. Comparison of healthy males and females revealed gender differences in creatine kinase, total protein and high-density lipoprotein cholesterol. Significant increases in the biochemical

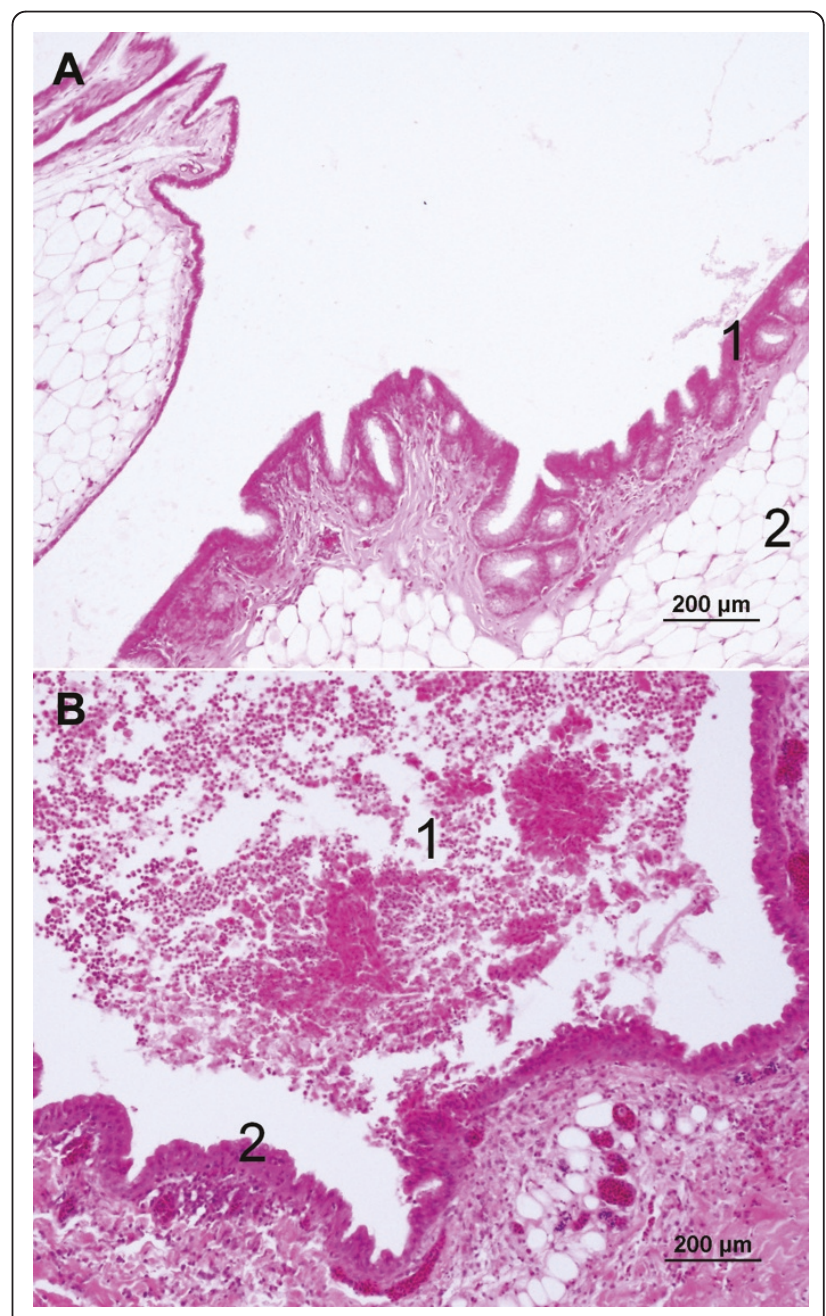

Figure 3 Comparison of normal and mycoplasmal infraorbital sinus demonstrating the serious nature of pathology in $M$. gallisepticum-infected birds. Figure 3A: The infraorbital sinus of a partridge from the control group. The sinus is lined with a simple columnar epithelium (1). The sinus is surrounded by adipose tissue (2). H\&E stain. Figure 3B: The infraorbital sinus of a partridge infected with $M$. gallisepticum. The sinus is richly filled with a dense purulent exudate (1). The epithelium is mildly hyperplastic and the lamina propria is focally infiltrated by lymphocytes and plasma cells (2). H\&E stain. 


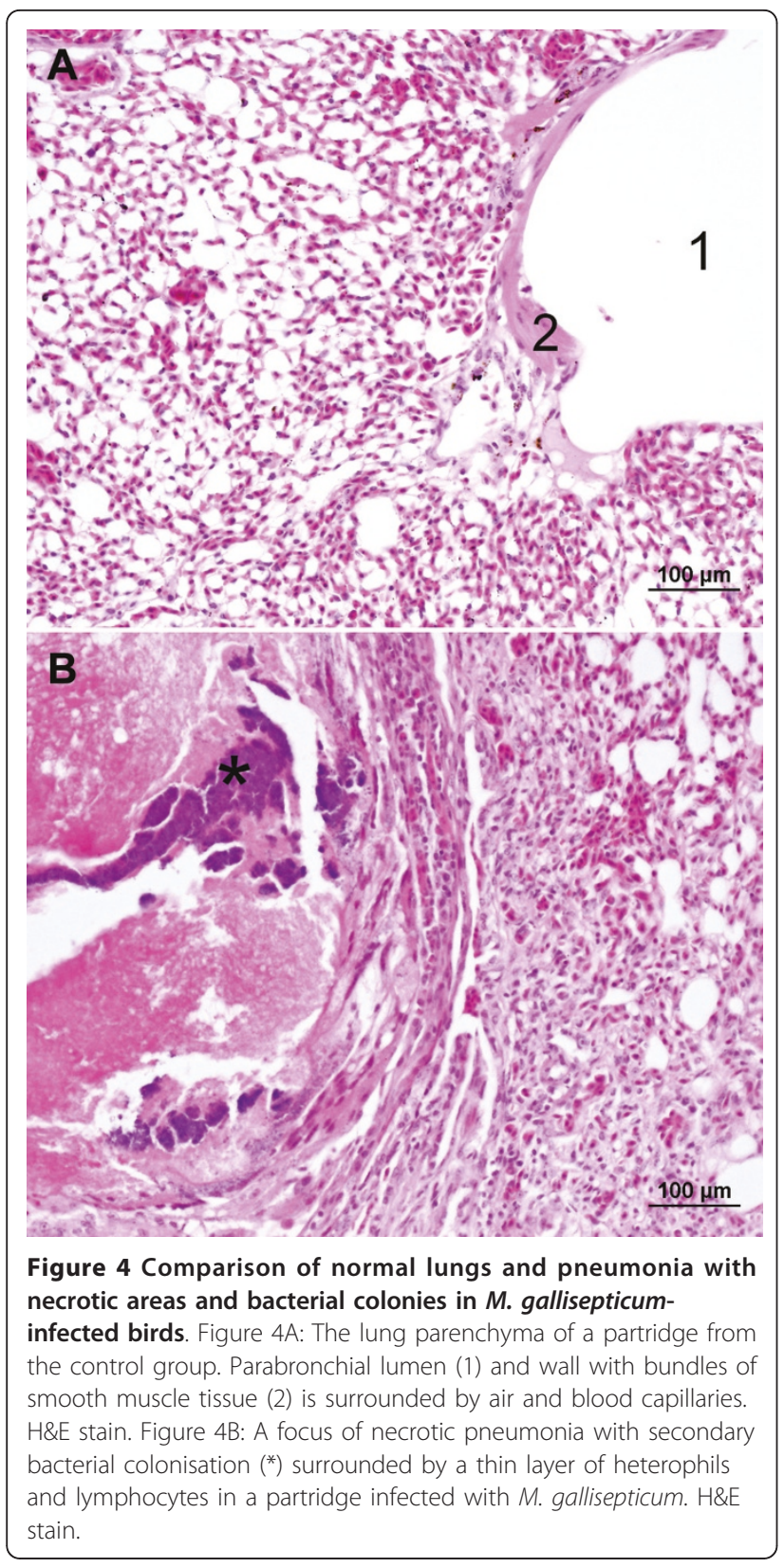

parameters of Mycoplasma-infected birds, when compared to controls, included activities of lactate dehydrogenase, creatine kinase and amylase, and levels of total protein and glucose.

Differences in antioxidant parameters between healthy control and Mycoplasma-infected grey partridges are shown in Table 2. While catalase showed significantly lower activity in the heart, lungs, liver and gonads of Mycoplasma-infected birds, glutathione-S-transferase was elevated in the eye and the associated infraorbital sinus and kidney, and decreased in the liver. Decreased levels of reduced glutathione were found in the heart, kidney, liver and gonads of birds affected by mycoplasmosis and the activity of glutathione reductase was lower only in the lungs. Compared to healthy birds, mycoplasmosis in the grey partridge caused significant differences in the level of lipid peroxidation measured as the total thiobarbituric acid reactive species in avian lungs and plasma. The ferric reducing antioxidant power was lower in the heart and kidneys.

As shown in Table 3, significant correlations among responses of the antioxidant parameters were found namely in the heart, lungs, spleen, liver and plasma. Reduced glutathione positively correlated with ferric reducing antioxidant power, glutathione reductase and catalase in the heart and with glutathione reductase, glutathione-S-transferase and catalase in the liver. There was also a positive correlation between glutathione reductase and catalase and ferric reducing antioxidant power in lungs and spleen, respectively, while glutathione-S-transferase and ferric reducing antioxidant power were in a close positive relationship with catalase both in the liver and plasma. Table 3 also presents numerous significant inter-tissue correlations of all the studied antioxidant parameters. Apart from glutathione$\mathrm{S}$-transferase in lungs and plasma and reduced glutathione in heart and plasma, all other inter-tissue correlations were positive.

\section{Discussion}

The outbreak of respiratory disease occurred at the peak of the laying period four months after the introduction of new partridges, i.e., the supposed source of infection in the game bird farm. The long incubation period is in agreement with reports on birds remaining asymptomatic until they are stressed [11]. The disease broke out long after removing the birds from the one-month quarantine and the stress of the laying period was probably the factor triggering clinical manifestation. Pheasants and partridges are known to harbour many fast-growing mycoplasmas, making the isolation of the slower-growing M. gallisepticum difficult [13]. In the present study, however, the isolation and identification of this mycoplasma species was straightforward. The high titres against $M$. gallisepticum together with its cultural and PCR identification witness for an ongoing systemic M. gallisepticum infection. While the high morbidity in the grey partridge flock corresponds with rates observed both in poultry and other avian species infected by M. gallisepticum as the sole pathogen, the high mortality is rather typical for mycoplasmosis complicated by some other infectious agent $[11-15,32]$. Indeed, E. coli was cultured from infraorbital sinuses, lungs and air sacs of some mycoplasmal birds and there were bacterial colonies in the lungs upon investigation by histopathology. It has been experimentally shown that combined stressors exert enhanced effects in birds [33], and, apart from E. coli, other bacteria 
Table 1 Differences in biochemical parameters between healthy control and Mycoplasma-infected partridges

\begin{tabular}{|c|c|c|}
\hline Parameters & Groups o & \\
\hline & Healthy control birds & Mycoplasma-infected birds \\
\hline AST ( $\mu$ kat/l) & $4.88 \pm 1.93$ & $4.84 \pm 1.35$ \\
\hline ALP ( $\mu$ kat/l) & $3.79 \pm 1.64$ & $3.42 \pm 1.75$ \\
\hline LDH ( $\mu$ kat/l) & $2.55 \pm 1.35$ & $8.20 \pm 3.47^{* *}$ \\
\hline CK $(\mu$ kat $/ \mathrm{l})$ & $11.58 \pm 13.30\left(\mathrm{M} 17.21 \pm 15.60 ;\right.$ F $\left.5.94 \pm 7.05^{* *}\right)$ & $28.88 \pm 18.13^{* *}$ \\
\hline ALT ( $\mu$ kat/l) & $0.69 \pm 0.13$ & $0.62 \pm 0.26$ \\
\hline $\mathrm{TP}(\mathrm{g} / \mathrm{l})$ & $38.62 \pm 7.99\left(\mathrm{M} 36.52 \pm 5.36 ;\right.$ F $\left.40.76 \pm 9.59^{*}\right)$ & $54.16 \pm 9.64^{* *}$ \\
\hline $\mathrm{T}-\mathrm{CHOL}(\mathrm{mmol} / \mathrm{l})$ & $3.17 \pm 1.00$ & $3.70 \pm 0.83$ \\
\hline HDL-CHOL (mmol/l) & $2.30 \pm 0.75\left(\mathrm{M} 2.54 \pm 0.80 ; \mathrm{F} 2.06 \pm 0.63^{* *}\right)$ & $1.95 \pm 0.40$ \\
\hline TG $(\mathrm{mmol} / \mathrm{l})$ & $1.31 \pm 0.65$ & $1.02 \pm 0.80$ \\
\hline GLU (mmol/l) & $18.90 \pm 2.60$ & $21.68 \pm 4.91^{*}$ \\
\hline AMY $(\mu \mathrm{kat} / \mathrm{l})$ & $3.50 \pm 1.47$ & $5.98 \pm 1.52^{* *}$ \\
\hline UAC $(\mu \mathrm{mol} / \mathrm{l})$ & $608.46 \pm 418.91$ & $918.66 \pm 445.45$ \\
\hline $\mathrm{Ca}(\mathrm{mmol} / \mathrm{l})$ & $2.63 \pm 0.25$ & $2.84 \pm 0.22$ \\
\hline $\mathrm{P}(\mathrm{mmol} / \mathrm{l})$ & $0.98 \pm 0.41$ & $1.09 \pm 0.50$ \\
\hline
\end{tabular}

Values represent mean $\pm S D ; n=88$ in healthy control birds (44 males and 44 females), $n=10$ in Mycoplasma-infected birds; ${ }^{*}=p<0.05,{ }^{*}=p<0.01$; significant gender differences shown where appropriate. AST $=$ aspartate aminotransferase, $\mathrm{ALP}=$ alkaline phosphatase, $\mathrm{LDH}=\mathrm{lactate}$ dehydrogenase, $\mathrm{CK}=$ creatine kinase, $\mathrm{ALT}=$ alanine aminotransferase, $\mathrm{TP}=$ total protein, $\mathrm{T}-\mathrm{CHOL}=$ total cholesterol, $\mathrm{HDL}-\mathrm{CHOL}=$ high-density lipoprotein cholesterol, $\mathrm{TG}=$ triglycerides, $\mathrm{GLU}=$ glucose, $\mathrm{AMY}=$ amylase, $\mathrm{UAC}=$ uric acid, $\mathrm{Ca}=$ calcium, $\mathrm{P}=$ phosphorus, $\mathrm{M}=$ male, and $\mathrm{F}=$ female.

and viruses such as Pasteurella multocida and infectious bronchitis virus, respectively, may be implicated in synergistic respiratory infections with $M$. gallisepticum [13-15]. Serology, however, excluded other common respiratory infections in birds included in the control healthy and Mycoplasma-infected groups of partridges.

Mycoplasmosis affecting birds in the laying period results in reduced egg production and quality [11]. The quantity of eggs laid by the grey partridge breeding flock decreased abruptly following the disease outbreak and eggs produced were not incubated to prevent contamination of the hatching device. It was, therefore, not possible to evaluate the biological quality of the clutch using such characteristics as viability and hatchability. Since an immune challenge decreases the reproductive allocation to the egg in the grey partridge [34], mycoplasmas are egg transmitted [11], and mycoplasmosis can also induce salpingitis in birds [35], the total effect of hatching (i.e., the percentage of chicks hatching from all eggs set) would certainly be very poor if the eggs were incubated.

Gross and microscopic pathology was specifically used to demonstrate the severity of the disease in grey partridges affected by $M$. gallisepticum in this biochemical study. Previous papers have reported sinusitis and bilateral swelling of the infraorbital sinuses as the most outstanding feature, airsacculitis in 46\%, and tracheitis and lung lesions in 36 and $21 \%$ of cases, respectively $[11,14,15]$. Comparing the effects of experimental intranasal infection with M. gallisepticum and Mycoplasma imitans in red-legged partridges, nasal and sinus exudates were found in both groups, while tracheal exudates and airsacculitis were only seen in the M. gallisepticum infection [14]. As the culture revealed $M$. gallisepticum in tracheal swabs and changes in the grey partridge were very similar to those mentioned above, pathological findings of the present study were in agreement with those observed by other authors $[11,14,15]$.

As shown in Table 1, gender differences in healthy control birds do not interfere with the interpretation of significant responses in plasma chemical profiles of Mycoplasma-infected partridges. The results indicate that diagnosis of avian mycoplasmosis solely based on clinical biochemical parameters is not possible. They can, nevertheless, be used for the evaluation of the general health status in mycoplasmal birds [36]. One would expect lower total protein and glucose due to starvation and weight loss in the Mycoplasma-infected group. Contrary to this, there was an increase in total plasma protein and glucose levels, probably as a consequence of inflammation or dehydration in the former parameter and stress in the latter. A response somewhat different from that in partridges was seen in caprine mycoplasmal pneumonia because total protein level was found to be lower, while the glucose level was increased [37]. Amylase catalyses the hydrolysis of polysaccharides, it is associated with glycaemia and its increase corresponds with the observed higher levels of glucose [38]. Both enzymes activities of which were significantly increased in mycoplasmal partridges, i.e., lactate dehydrogenase and creatine kinase, are closely associated. Lactate dehydrogenase is found in skeletal and cardiac muscle, liver, 
Table 2 Differences in antioxidant parameters between healthy control and Mycoplasma-infected partridges

\begin{tabular}{|c|c|c|c|}
\hline \multirow[t]{2}{*}{ Parameters } & \multirow[t]{2}{*}{ Tissues } & \multicolumn{2}{|c|}{ Groups of birds } \\
\hline & & Healthy control birds & Mycoplasma-infected birds \\
\hline \multirow[t]{9}{*}{ CAT } & Eye + infraorbital sinus & $61.80 \pm 23.37$ & $48.91 \pm 16.63$ \\
\hline & Heart & $66.90 \pm 25.95$ & $39.28 \pm 4.40^{*}$ \\
\hline & Central nervous system & $41.57 \pm 9.09$ & $44.18 \pm 20.07$ \\
\hline & Lungs & $61.33 \pm 16.16$ & $38.34 \pm 11.34^{*}$ \\
\hline & Kidney & $48.18 \pm 14.89$ & $50.75 \pm 21.54$ \\
\hline & Spleen & $57.19 \pm 20.00$ & $40.19 \pm 8.81$ \\
\hline & Liver & $63.15 \pm 14.38$ & $43.36 \pm 6.43^{*}$ \\
\hline & Gonads (ovaries/testes) & $62.62 \pm 22.30$ & $36.95 \pm 11.37^{*}$ \\
\hline & Plasma & $59.67 \pm 12.88$ & $47.72 \pm 24.24$ \\
\hline \multirow[t]{9}{*}{ GST } & Eye + infraorbital sinus & $19.49 \pm 12.55$ & $46.06 \pm 19.41^{*}$ \\
\hline & Heart & $134.16 \pm 43.02$ & $215.66 \pm 98.39$ \\
\hline & Central nervous system & $53.21 \pm 34.50$ & $80.41 \pm 32.21$ \\
\hline & Lungs & $67.70 \pm 35.61$ & $69.44 \pm 34.74$ \\
\hline & Kidney & $236.40 \pm 72.85$ & $362.33 \pm 64.05^{*}$ \\
\hline & Spleen & $25.08 \pm 18.82$ & $71.66 \pm 67.29$ \\
\hline & Liver & $389.80 \pm 92.82$ & $254.33 \pm 98.20^{*}$ \\
\hline & Gonads (ovaries/testes) & $134.16 \pm 43.02$ & $215.68 \pm 98.37$ \\
\hline & Plasma & $645.83 \pm 90.52$ & $461.80 \pm 157.78$ \\
\hline \multirow[t]{9}{*}{ GSH } & Eye + infraorbital sinus & $2.00 \pm 0.04$ & $1.929 \pm 0.15$ \\
\hline & Heart & $1.78 \pm 0.04$ & $1.33 \pm 0.03^{* *}$ \\
\hline & Central nervous system & $2.03 \pm 0.17$ & $1.91 \pm 0.10$ \\
\hline & Lungs & $1.76 \pm 0.05$ & $1.73 \pm 0.17$ \\
\hline & Kidney & $1.82 \pm 0.20$ & $1.44 \pm 0.17^{* *}$ \\
\hline & Spleen & $1.79 \pm 0.06$ & $1.83 \pm 0.05$ \\
\hline & Liver & $2.35 \pm 0.30$ & $1.59 \pm 0.12^{* *}$ \\
\hline & Gonads (ovaries/testes) & $1.91 \pm 0.17$ & $1.49 \pm 0.32^{*}$ \\
\hline & Plasma & $212.52 \pm 4.04$ & $232.93 \pm 17.27^{*}$ \\
\hline \multirow[t]{9}{*}{ GR } & Eye + infraorbital sinus & $2.46 \pm 0.87$ & $3.48 \pm 1.51$ \\
\hline & Heart & $28.45 \pm 25.82$ & $7.27 \pm 2.34$ \\
\hline & Central nervous system & $7.82 \pm 3.49$ & $5.49 \pm 2.73$ \\
\hline & Lungs & $57.55 \pm 13.07$ & $26.34 \pm 9.31^{* *}$ \\
\hline & Kidney & $36.44 \pm 8.84$ & $39.03 \pm 9.00$ \\
\hline & Spleen & $28.99 \pm 12.22$ & $24.16 \pm 16.51$ \\
\hline & Liver & $53.32 \pm 15.68$ & $36.70 \pm 9.55$ \\
\hline & Gonads (ovaries/testes) & $10.93 \pm 6.74$ & $8.57 \pm 3.58$ \\
\hline & Plasma & $529.20 \pm 392.81$ & $321.54 \pm 84.73$ \\
\hline \multirow[t]{9}{*}{ TBARS } & Eye + infraorbital sinus & $0.14 \pm 0.03$ & $0.15 \pm 0.03$ \\
\hline & Heart & $0.14 \pm 0.01$ & $0.17 \pm 0.04$ \\
\hline & Central nervous system & $0.19 \pm 0.04$ & $0.18 \pm 0.03$ \\
\hline & Lungs & $0.09 \pm 0.02$ & $0.14 \pm 0.02^{*}$ \\
\hline & Kidney & $0.20 \pm 0.04$ & $0.18 \pm 0.04$ \\
\hline & Spleen & $0.14 \pm 0.01$ & $0.17 \pm 0.04$ \\
\hline & Liver & $0.14 \pm 0.01$ & $0.17 \pm 0.04$ \\
\hline & Gonads (ovaries/testes) & $0.14 \pm 0.01$ & $0.17 \pm 0.04$ \\
\hline & Plasma & $216.46 \pm 47.06$ & $133.32 \pm 59.80^{*}$ \\
\hline
\end{tabular}


Table 2 Differences in antioxidant parameters between healthy control and Mycoplasma-infected partridges (Continued)

\begin{tabular}{|c|c|c|c|}
\hline FRAP & Eye + infraorbital sinus & $4.52 \pm 1.31$ & $2.76 \pm 1.27$ \\
\hline & Heart & $1.96 \pm 0.27$ & $1.52 \pm 0.12^{* *}$ \\
\hline & Central nervous system & $2.09 \pm 0.31$ & $2.00 \pm 0.11$ \\
\hline & Lungs & $1.72 \pm 0.44$ & $1.77 \pm 0.43$ \\
\hline & Kidney & $6.84 \pm 0.93$ & $3.77 \pm 1.62^{* *}$ \\
\hline & Spleen & $4.52 \pm 1.31$ & $2.76 \pm 1.27$ \\
\hline & Liver & $1.72 \pm 0.44$ & $1.77 \pm 0.43$ \\
\hline & Gonads (ovaries/testes) & $2.47 \pm 0.63$ & $3.11 \pm 1.01$ \\
\hline & Plasma (mmol/g) & $1.72 \pm 0.44$ & $1.77 \pm 0.43$ \\
\hline
\end{tabular}

Values represent mean \pm SD; $\mathrm{n}=10$ in healthy control birds ( 5 males and 5 females), $\mathrm{n}=10$ in Mycoplasma-infected birds (5 males and 5 females); $=\mathrm{p}<0.05$, $* *=p<0.01$. CAT = catalase $\left(\mu \mathrm{mol} \mathrm{H}_{2} \mathrm{O}_{2} / \mathrm{min} / \mathrm{mg}\right.$ protein), GST = glutathione-S-transferase $(\mu \mathrm{kat} / \mathrm{g}), \mathrm{GSH}=$ reduced glutathione $(\mu \mathrm{mol} / \mathrm{g}), \mathrm{GR}=\mathrm{glutathione}$ reductase $(\mu \mathrm{kat} / \mathrm{g})$, TBARS $=$ total thiobarbituric acid reactive species $(\mu \mathrm{mol} / \mathrm{g}), \mathrm{FRAP}=$ ferric reducing antioxidant power assay $(\mu \mathrm{mol} / \mathrm{g})$.

kidney, bone and erythrocytes and elevations can be observed with disruption of any of these. Distinguishing the source of lactate dehydrogenase elevation is based on measuring creatine kinase that originates mainly in skeletal and cardiac muscle. Elevated lactate dehydrogenase levels (three-fold) with concurrent elevation in creatine kinase (two-fold) in the present study are thus suggestive of skeletal or cardiac muscle damage [36].

The research presented here showed modulations of antioxidant parameters, the total antioxidant capacity and oxidative damage in the form of lipid peroxidation associated with the respiratory disease caused by a natural infection with $M$. gallisepticum of grey partridges. Oxidative stress is an unspecific biochemical process involved in the adverse action of many stressors. There is a clear association between oxidative stress and immune responses of birds to infectious agents [39]. Endogenous antioxidant defences of an enzymatic and non-enzymatic nature are essential for the control of reactive-molecular-speciesmediated oxidative damage of biomolecules [40]. Interestingly, changes in oxidative stress parameters were not restricted to the respiratory apparatus of mycoplasmal birds, but also occurred in non-respiratory organs and plasma. Similarly, extrapulmonary complications were recognised in humans with M. pneumoniae infection [41]. Statistical analysis also revealed significant correlations among responses of the oxidative stress parameters in the heart, lungs, spleen, liver and plasma, and numerous intertissue correlations of all the studied oxidative stress parameters. Correlations among the oxidative stress parameters illustrate the complex character of the response and interdependence of parameters. Significant correlations among the studied parameters observed in the liver confirm the major metabolic role of this organ in birds. It would be an interesting issue for future studies to evaluate the relationship between the tissue mycoplasmal burden and oxidative stress parameters, as has been done in other bacterial infections [42].
Hydrogen peroxide and superoxide radicals produced by mycoplasmas are coupled with endogenous toxic oxygen molecules generated by the host cells to induce oxidative stress that then results in host cell damage [24,41]. It has been suggested that the pathogenesis of mycoplasmosis comprises the following sequence of events: (a) adherence of mycoplasmas to host cells; (b) generation of superoxide and hydrogen peroxide by the microorganisms and their introduction into host cells; (c) irreversible inhibition of host cell catalase by intracellular reactiveoxygen-species accumulation; and (d) oxidative damage to vital cell constituents $[18,19,22]$. In agreement with the above mentioned in vitro findings, catalase showed significantly lower activity in the heart, lungs, liver and gonads of Mycoplasma-infected partridges.

Significant changes were found for the glutathionerelated parameters. Glutathione-S-transferase was elevated in the eye and the associated infraorbital sinus and kidney, and decreased in the liver. Decreased levels of reduced glutathione were in the heart, kidney, liver and gonads and the activity of glutathione reductase was lower only in the lungs of birds affected by mycoplasmosis. These results correspond basically with data on the protective role of the glutathione redox cycle and its adaptive responses observed in cultured fibroblasts and mice infected with M. pneumoniae, respectively [20,23]. Similarly, decreases in plasma glutathione concentrations and glutathione peroxidase activity were reported in goats naturally infected with M. agalactiae [25].

It is possible to evaluate the total antioxidant capacity of biological fluids using the ferric reducing antioxidant power assay as a clinical marker of oxidative stress. Non-enzymatic antioxidants such as ascorbic acid, uric acid, bilirubin, vitamin E, $\alpha$-tocopherol and albumin contribute to the ferric reducing antioxidant power, the reaction is linearly related to their molar concentrations, and uric acid is estimated to make around $60 \%$ of the contribution to the plasma value [31]. Importantly, the 
Table 3 Spearman rank order correlations of antioxidant parameters in tissues and plasma

\begin{tabular}{|c|c|c|c|}
\hline Tissue & Correlated parameters & +/- correlation & P-level \\
\hline \multirow[t]{3}{*}{ Heart } & GSH\&FRAP & + & $<0.01$ \\
\hline & GSH\&GR & + & $<0.05$ \\
\hline & GSH\&CAT & + & $<0.05$ \\
\hline Lungs & GR\&CAT & + & $<0.05$ \\
\hline Spleen & GR\&FRAP & + & $<0.01$ \\
\hline \multirow[t]{4}{*}{ Liver } & GSH\&GR & + & $<0.05$ \\
\hline & GSH\&GST & + & $<0.01$ \\
\hline & GSH\&CAT & + & $<0.01$ \\
\hline & GST\&CAT & + & $<0.05$ \\
\hline Plasma & FRAP\&CAT & + & $<0.05$ \\
\hline Parameters & Correlated tissues & +/- correlation & P-level \\
\hline \multirow[t]{8}{*}{$\overline{\text { CAT }}$} & Heart \& gonads & + & $<0.01$ \\
\hline & Heart \& liver & + & $<0.05$ \\
\hline & Eye \& lungs & + & $<0.05$ \\
\hline & CNS \& kidney & + & $<0.05$ \\
\hline & Lungs \& liver & + & $<0.05$ \\
\hline & Lungs \& plasma & + & $<0.05$ \\
\hline & Kidney \& plasma & + & $<0.05$ \\
\hline & Gonads \& liver & + & $<0.01$ \\
\hline \multirow[t]{7}{*}{ GST } & Heart \& eye & + & $<0.05$ \\
\hline & Heart \& gonads & + & $<0.001$ \\
\hline & Heart \& spleen & + & $<0.05$ \\
\hline & Eye \& gonads & + & $<0.01$ \\
\hline & Eye \& spleen & + & $<0.01$ \\
\hline & Lungs \& plasma & - & $<0.05$ \\
\hline & Gonads \& spleen & + & $<0.05$ \\
\hline \multirow[t]{7}{*}{$\overline{\mathrm{GSH}}$} & Heart \& kidney & + & $<0.01$ \\
\hline & Heart \& gonads & + & $<0.05$ \\
\hline & Heart \& liver & + & $<0.001$ \\
\hline & Heart \& plasma & - & $<0.01$ \\
\hline & Eye \& gonads & + & $<0.05$ \\
\hline & Kidney \& liver & + & $<0.01$ \\
\hline & Gonads \& liver & + & $<0.05$ \\
\hline$\overline{\mathrm{GR}}$ & Heart \& plasma & + & $<0.05$ \\
\hline \multirow[t]{7}{*}{ TBARS } & Heart \& lungs & + & $<0.05$ \\
\hline & Heart \& gonads & + & $<0.001$ \\
\hline & Heart \& spleen & + & $<0.001$ \\
\hline & Heart \& liver & + & $<0.001$ \\
\hline & Lungs \& gonads & + & $<0.05$ \\
\hline & Lungs \& spleen & + & $<0.05$ \\
\hline & Lungs \& liver & + & $<0.05$ \\
\hline \multirow[t]{3}{*}{ FRAP } & Eye \& spleen & + & $<0.001$ \\
\hline & Lungs \& plasma & + & $<0.001$ \\
\hline & Liver \& plasma & + & $<0.001$ \\
\hline
\end{tabular}

CAT = catalase, GST = glutathione-S-transferase, GSH = reduced glutathione, GR $=$ glutathione reductase, TBARS $=$ total thiobarbituric acid reactive species, FRAP $=$ ferric reducing antioxidant power assay, eye $=$ eye + the associated infraorbital sinus, CNS = central nervous system, gonads = ovaries or testes, $\mathrm{n}=20$. primary route of excretion of nitrogenous waste in birds is via the formation of uric acid in the liver and its elimination by renal tubular secretion [36]. As shown in Table 1, uric acid levels were increased in the blood of mycoplasmal birds, but not significantly owing to the greater variability of data. Despite it, the total antioxidant capacity of plasma was nearly the same in both groups of birds and agreed with normal plasma values already published for the grey partridge [43]. The ferric reducing antioxidant power values were significantly lower only in the heart and kidneys of Mycoplasmainfected birds.

While ingested carotenoids are both ornamental pigments and antioxidants in birds, M. gallisepticum infection can disrupt their utilisation and result in a trade-off between immune system activation, oxidative stress and the health or sexual quality traits $[44,45]$. These and other diet-derived antioxidants can therefore be supplemented to feeds for Mycoplasma-infected captive birds as a means of supportive therapy.

Compared to healthy birds, mycoplasmosis in the grey partridge caused significant differences in the level of lipid peroxidation, i.e., a parameter of damage to membrane lipids, measured as the total thiobarbituric acid reactive species in avian lungs and plasma. Contrary to the situation in goats naturally infected with $M$. agalactiae [25], lipid peroxidation was decreased in plasma samples collected from mycoplasmal partridges. This is, however, understandable in light of the birds from the group infected by $M$. gallisepticum being able to maintain normal blood antioxidant capacity and induction of higher levels of the non-enzymatic antioxidant glutathione. As expected, avian mycoplasmosis was associated with increased lipid peroxidation in the lungs.

Mycoplasmas are considered to be extracellular pathogens. It has, however, been demonstrated recently that M. gallisepticum has the capability of entering nonphagocytic host cells, where it resists host defences and antibiotic therapy. This is also a mechanism of establishing chronic infections, while passage through the respiratory mucosal barrier is responsible for the ability to cause systemic infections [46]. As eradication is very difficult or even impossible once $M$. gallisepticum has been introduced, the breeding flock of grey partridges should be depopulated rather than used for repopulation [11].

\section{Conclusions}

The present study demonstrated the high susceptibility of grey partridges to a natural infection with M. gallisepticum, the severity of the disease based on histopathology and the biochemical responses to mycoplasmosis in this avian host. While the reported data make a contribution to the understanding of the pathogenic mechanisms of mycoplasmal respiratory disease in birds, the normal biochemistry and antioxidant parameters of 
tissues and plasma may also prove useful as future references in experimental studies, and clinical or laboratory tests using grey partridges.

\section{Acknowledgements}

This study was supported by the Ministry of Education, Youth and Sports of the Czech Republic and the Internal Grant Agency of the University of Veterinary and Pharmaceutical Sciences Brno (Projects MSM 6215712402 and 80/2010/FVHE, respectively).

\section{Author details}

'Department of Veterinary Ecology and Environmental Protection, Faculty of Veterinary Hygiene and Ecology, University of Veterinary and Pharmaceutical Sciences, Brno, Czech Republic. ${ }^{2}$ Centre of Advanced Studies, Faculty of Military Health Sciences, University of Defence, Hradec Kralove, Czech Republic. ${ }^{3}$ Department of Pathological Morphology and Parasitology, Faculty of Veterinary Medicine, University of Veterinary and Pharmaceutical Sciences, Brno, Czech Republic. ${ }^{4}$ Department of Infectious Diseases and Microbiology, Faculty of Veterinary Medicine, University of Veterinary and Pharmaceutical Sciences, Brno, Czech Republic.

\section{Authors' contributions}

FV carried out the whole study and drafted the manuscript. LP, HB, DJ, JK, $\mathrm{KO}$ and $\mathrm{JO}$ planned the study design, sampled the birds and performed biochemical evaluations. MP analysed plasma and tissue samples for antioxidant parameters and lipid peroxidation. LN evaluated histopathological findings. DZ performed mycoplasmal culture. KR examined the isolated mycoplasmas using the nested PCR. FT evaluated the outbreak of avian mycoplasmosis in the breeding flock of partridges. JP supervised the whole study, performed data analyses and drafted the manuscript. All authors read and approved the final manuscript.

Received: 19 March 2011 Accepted: 8 July 2011 Published: 8 July 2011

\section{References}

1. BirdLife International (2011) Species factsheet: Perdix perdix. [http://www. birdlife.org].

2. Kuijper DPJ, Oosterveld E, Wymenga E: Decline and potential recovery of the European grey partridge (Perdix perdix) population - a review. Eur $J$ Wildl Res 2009, 55(5):455-463.

3. Rantanen EM, Buner F, Riordan P, Sotherton N, Macdonald DW: Habitat preferences and survival in wildlife reintroductions: an ecological trap in reintroduced grey partridges. J Appl Ecol 2010, 47(6):1357-1364.

4. Wiberg S, Gunnarsson S: Health and welfare in Swedish game bird rearing. In Sustainable Animal Production - the Challenges and Potential Developments for Professional Farming. Edited by: Aland A, Madec F. Wageningen: Wageningen Academic Publishers; 2009:395-407.

5. Meriggi A, Brangi A, Cuccus P, Della Stella RM: High mortality rate in a reintroduced grey partridge population in central Italy. Ital I Zool 2002, 69(1):19-24.

6. Gortazar C, Acevedo P, Ruiz-Fons F, Vicente J: Disease risks and overabundance of game species. Eur J Wildl Res 2006, 52(2):81-87.

7. Liukkonen T: Finnish native grey partridge (Perdix perdix) population differs clearly in mitochondrial DNA from the farm stock used for releases. Ann Zool Fenn 2006, 43(3):271-279.

8. Millan J, Gortazar C, Villafuerte R: A comparison of the helminth faunas of wild and farm-reared red-legged partridge. J Wildl Manage 2004, 68(3):701-707.

9. Villanua D, Perez-Rodriguez L, Casas F, Alzaga V, Acevedo P, Vinuela J, Gortazar C: Sanitary risks of red-legged partridge releases: introduction of parasites. Eur J Wildl Res 2008, 54(2):199-204.

10. Bradbury JM: Poultry mycoplasmas: sophisticated pathogens in simple guise. Br Poult Sci 2005, 46(2):125-136.

11. Levisohn S, Kleven SH: Avian mycoplasmosis (Mycoplasma gallisepticum). Rev Sci Tech Off Int Epizoot 2000, 19(2):425-442.

12. Bencina D, Mrzel I, Rojs OZ, Bidovec A, Dove A: Characterisation of Mycoplasma gallisepticum strains involved in respiratory disease in pheasants and peafowl. Vet Rec 2003, 152(8):230-234.
13. Bradbury JM, Yavari CA, Dare CM: Mycoplasmas and respiratory disease in pheasants and partridges. Avian Pathol 2001, 30(4):391-396.

14. Ganapathy K, Bradbury JM: Pathogenicity of Mycoplasma gallisepticum and Mycoplasma imitans in red-legged partridges (Alectoris rufa). Avian Pathol 1998, 27(5):455-463.

15. Welchman DD, Bradbury JM, Cavanagh D, Aebischer NJ: Infectious agents associated with respiratory disease in pheasants. Vet Rec 2002, 150(21):658-664.

16. Benskin $\mathrm{CMH}$, Wilson $\mathrm{K}$, Jones $\mathrm{K}$, Hartley IR: Bacterial pathogens in wild birds: a review of the frequency and effects of infection. Biol Rev 2009, 84(3):349-373.

17. Williams ES, Yuill T, Artois M, Fischer J, Haigh SA: Emerging infectious diseases in wildlife. Rev Sci Tech Off Int Epizoot 2002, 21(1):139-157.

18. Almagor M, Yatziv $S$, Kahane I: Inhibition of host-cell catalase by Mycoplasma pneumoniae - a possible mechanism for cell injury. Infect Immun 1983, 41(1):251-256.

19. Almagor M, Kahane I, Yatziv S: Role of superoxide anion in host-cell injury induced by Mycoplasma pneumoniae infection - a study in normal and trisomy 21 cells. J Clin Invest 1984, 73(3):842-847.

20. Almagor M, Kahane I, Gilon C, Yatziv S: Protective effects of the glutathione redox cycle and vitamin $\mathrm{E}$ on cultured fibroblasts infected by Mycoplasma pneumoniae. Infect Immun 1986, 52(1):240-244.

21. Jenkins C, Samudrala R, Geary SJ, Djordjevic SP: Structural and functional characterization of an organic hydroperoxide resistance protein from Mycoplasma gallisepticum. J Bacteriol 2008, 190(6):2206-2216.

22. Nunoya T, Tajima M, Yagihashi T: Decrease in catalase activity of cultured cells by Mycoplasma gallisepticum infection. Vet Microbiol 1987, 13(4):343-351.

23. Kariya C, Chu HW, Huang J, Leitner H, Martin RJ, Day BJ: Mycoplasma pneumoniae infection and environmental tobacco smoke inhibit lung glutathione adaptive responses and increase oxidative stress. Infect Immun 2008, 76(10):4455-4462.

24. Sun GP, Xu XF, Wang YS, Shen XY, Chen ZM, Yang J: Mycoplasma pneumoniae infection induces reactive oxygen species and DNA damage in A549 human lung carcinoma cells. Infect Immun 2008, 76(10):4405-4413.

25. Kizil O, Ozdemir H, Karahan M, Kizil M: Oxidative stress and alterations of antioxidant status in goats naturally infected with Mycoplasma agalactiae. Rev Med Vet 2007, 158(6):326-330.

26. Bradbury JB: Recovery of Mycoplasmas from birds. In Methods in Molecular Biology. Volume 104. Edited by: Miles RJ, Nicholas RAJ. New Jersey: Humana Press Inc; 1998:45-51.

27. Edward DG: A selective medium for pleuropneumonia-like organisms. J Gen Microbiol 1947, 1:238-243.

28. Bradbury JM: Rapid biochemical tests for characterization of the Mycoplasmatales. J Clin Microbiol 1977, 5:531-534.

29. Paskova V, Adamovsky O, Pikula J, Skocovska B, Band'ouchova H, Horakova J, Babica P, Marsalek B, Hilcherova K: Detoxification and oxidative stress responses along with microcystins accumulation in Japanese quail exposed to cyanobacterial biomass. Sci Total Environ 2008, 398(1-3):34-47.

30. Aebi H: Catalase in vitro. Method Enzymol 1984, 105:121-126.

31. Benzie IFF, Strain JJ: The ferric reducing ability of plasma (FRAP) as a measure of "antioxidant power": the FRAP assay. Anal Biochem 1996, 239(1):70-76.

32. Nunoya T, Yagihashi T, Tajima M, Nagasawa Y: Occurrence of keratoconjunctivitis apparently caused by Mycoplasma gallisepticum in layer chickens. Vet Pathol 1995, 32(1):11-18.

33. Pikula J, Bandouchova H, Hilscherova K, Paskova V, Sedlackova J, Adamovsky O, Knotkova Z, Lany P, Machat J, Marsalek B, Novotny L, Pohanka M, Vitula F: Combined exposure to cyanobacterial biomass, lead and the Newcastle virus enhances avian toxicity. Sci Total Environ 2010, 408(21):4984-4992.

34. Cucco M, Guasco B, Malacarne G, Ottonelli R: Effects of beta-carotene on adult immune condition and antibacterial activity in the eggs of the Grey Partridge, Perdix perdix. Comp Biochem Physiol A Mol Integr Physiol 2007, 147(4):1038-1046.

35. Domermut CH, Gross WB, Dubose RT: Mycoplasmal salpingitis of chickens and turkeys. Avian Dis 1967, 11(3):393-398. 
36. Fudge AM: Avian clinical pathology - hematology and chemistry. In Avian Medicine and Surgery.. 1 edition. Edited by: Altman RB, Clubb SL, Dorrestein GM, Quesenberry K. Philadelphia: W.B. Saunders Company; 1997:142-157.

37. Mondal D, Pramanik AK, Basak DK: Clinico-haematology and pathology of caprine mycoplasmal pneumonia in rain fed tropics of West Bengal. Small Ruminant Res 2004, 51(3):285-295.

38. Place AR: Birds and lipids: living off the fat of the earth. Poult Avian Biol Rev 1996, 7(2-3):127-141.

39. Costantini D, Moller AP: Does immune response cause oxidative stress in birds? A meta-analysis. Comp Biochem Physiol A Mol Integr Physiol 2009, 153(3):339-344.

40. Halliwell B, Gutteridge JMC: Free Radicals in Biology and Medicine. Oxford: Oxford University Press; 1999.

41. Waites KB, Talkington DF: Mycoplasma pneumoniae and its role as a human pathogen. Clin Microbiol Rev 2004, 17(4):697-728.

42. Bandouchova H, Sedlackova J, Pohanka M, Novotny L, Hubalek M, Treml F, Vitula F, Pikula J: Tularemia induces different biochemical responses in BALB/c mice and common voles. BMC Infect Dis 2009, 9:9.

43. Pohanka M, Bandouchova H, Vlckova K, Zdarova Karasova J, Kuca K, Damkova V, Peckova L, Vitula F, Pikula J: Square wave voltammetry on screen printed electrodes: comparison to ferric reducing antioxidant power in plasma from model laboratory animal (Grey Partridge) and comparison to standard antioxidants. J Appl Biomed 2011, 9:103-109.

44. Blount JD: Carotenoids and life-history evolution in animals. Arch Biochem Biophys 2004, 430(1):10-15.

45. Hill GE, Farmer KL, Beck ML: The effect of mycoplasmosis on carotenoid plumage coloration in male house finches. J Exp Biol 2004, 207(12):2095-2099.

46. Winner F, Rosengarten R, Citti C: In vitro cell invasion of Mycoplasma gallisepticum. Infect Immun 2000, 68:4238-4244.

doi:10.1186/1746-6148-7-34

Cite this article as: Vitula et al: Mycoplasma gallisepticum infection in the grey partridge Perdix perdix: outbreak description, histopathology, biochemistry and antioxidant parameters. BMC Veterinary Research 2011 7:34.

\section{Submit your next manuscript to BioMed Central and take full advantage of:}

- Convenient online submission

- Thorough peer review

- No space constraints or color figure charges

- Immediate publication on acceptance

- Inclusion in PubMed, CAS, Scopus and Google Scholar

- Research which is freely available for redistribution

Submit your manuscript at www.biomedcentral.com/submit 